ISSN 2355-309X

\title{
PENGARUH KEPERCAYAAN DAN PERSEPSI RISIKO TERHADAP KEPUTUSAN PEMBELIAN E-COMMERCE PADA TOKOPEDIA.COM DI JAKARTA PUSAT
}

\author{
Heksawan Rahmadi \& Deni Malik \\ Institut Ilmu Sosial dan Manajemen STIAMI \\ heksawan@stiami.ac.id
}

\begin{abstract}
Abstrak. Penelitan ini dilakukan dengan tujuan untuk mengetahui : (1) pengaruh kepercayaan terhadap keputusan pembelian e-commerce pada Tokopedia.com di Jakarta Pusat. (2) pengaruh persepsi risiko terhadap keputusan pembelian e-commerce pada Tokopedia.com di Jakarta Pusat (3) pengaruh kepercayaan dan persepsi risiko terhadap keputusan pembelian e-commerce pada Tokopedia.com di Jakarta Pusat. Jenis penelitian yang digunakan dalam penelitian ini adalah survei. Populasi dalam penelitian ini adalah seluruh pengguna Tokopedia.com di Jakarta Pusat yang mengetahui situs Tokopedia.com. Teknik pengambilan sampel menggunakan metode purposive sampling dengan jumlah sampel sebanyak 105 orang. Teknik pengumpulan data menggunakan kuesioner yang telah diuji validitas dan reliabilitasnya. Teknik analisis data yang digunakan untuk menjawab hipotesis adalah analisis regresi linier berganda. Hasil penelitian ini menunjukkan bahwa (1) terdapat pengaruh positif kepercayaan terhadap keputusan pembelian e-commerce pada Tokopedia.com di Jakarta Pusat sebesar 13.5\%. Hal ini dibuktikan dari nilai t hitung sebesar 4,020 dengan nilai signifikansi sebesar 0,000 lebih kecil dari $0,05(0,000<0,05)$. (2) terdapat pengaruh negatif persepsi risiko terhadap keputusan pembelian e-commerce pada Tokopedia.com di Jakarta Pusat. Hal ini dibuktikan dari nilai t hitung sebesar -0,796 dengan nilai signifikansi sebesar 0,428 lebih besar dari 0,05 $(0,428>0,000)$. (3) terdapat pengaruh positif kepercayaan dan persepsi risiko terhadap keputusan pembelian e-commerce pada Tokopedia.com di Jakarta Pusat sebesar 14.1\%. Hal ini dibuktikan dengan hasil pengujian diperoleh nilai $\mathrm{F}$ hitung sebesar 8,354 dengan signifikansi $0,000(0,000<0,50)$. Berdasarkan hal tersebut, maka disarankan agar terus meningkatkan kepercayaan konsumen dengan meminimalisir risiko-risiko yang ada pada transaksi perdagangan elektronik guna mencapai kepuasan konsumen sehingga merekomendasikan pembelian kepada yang lainnya.
\end{abstract}

Kata Kunci: Pengaruh, Kepercayaan, Persepsi Risiko, Keputusan Pembelian.

Abstract. This research aim to determine : (1) the effect of trust toward on purchasing decisions on Tokopedia at Central Jakarta. (2) the effect od perceived risk towardon purchasing decisions on Tokopedia at Cental Jakarta. (3) the effect of trust and perceived risk toward on purchasing decisions on Tokopedia at Central Jakarta. The type of research used in this study was a survey. The population in this study was citizens of Central Jakarta familiar with Tokopedia.com site. The total sample of 150 people. The data collection technique used in this study was quuestionnaire that has been tasted for validly and reliability. The data analysis technique employed in this study to answer the hypothesis was multiple regressions. The result of this study shows that : (1) There is a positive effect of trust toward on purchasing decisions on Tokopedia at Central Jakarta. It is proven from the value of 4,020 with 0,000 significance value of less than 0,05 (0,000<0,05). (2) There is a negative effect of perceived risk toward on purchasing decisions on Tokopedia at Central Jakarta. It is proven from the value of $-0,796$ with 0,428 significance value of more than 0,05 $(0,428>0,05)$. (3) There is a positive effect of trust and perceived risk toward on purchasing decisions on Tokopedia at Central Jakarta. It is proven from the value of 8,354 with 0,000 significance value of less than 0,05 (0,000<0,05). Based on this, it is recommended to continue to boost consumer confidence by minimizing the risks that exist in electronic commerce transactions in order to achieve customer satisfaction so that recommend the purchase to others.

Keywords: Influence, Trust, Risk Perception, Purchase Decision. 
Heksawan Rahmadi \& Deni Malik, Pengaruh Kepercayaan Dan Persepsi Risiko ...

\section{PENDAHULUAN}

Di era digital yang terus berkembang seperti saat ini, pertumbuhan ekonomi menjadi sangat bergantung pada teknologi dan internet. Hal ini terbukti dari pertumbuhan internet di Indonesia yang terus mengalami peningkatan. Internet merupakan sarana elektronik yang dapat dipergunakan untuk berbagai aktivitas seperti komunikasi, riset, pemanfaatan informasi dan juga dapat digunakan sebagai sarana untuk melakukan transaksi perdagangan.

Menurut data yang dikeluarkan oleh Kemenkominfo jumlah pengguna Internet di Indonesia pada tahun 2015 sudah mencapai 93,4 juta jiwa dengan 7,4 juta konsumen online dan dengan nilai transaksi mencapai US\$3,65 Miliar. Pada tahun 2016 diperkirakan ada 8.7 juta konsumen toko online dengan nilai transaksi US $\$ 4,89$ miliar dan di proyeksikan akan terus meningkat secara siginifikan pada tahun yang akan mendatang (https:kominfo.go.id).

Selain itu, berdasarkan data yang dipublikasikan WeAreSocial, penetrasi internet di Indonesia pada tahun 2016 tercatat sebesar 34 persen, meningkat dibandingkan tahun sebelumnya yang sebesar 28 persen. Tercatat, pengguna internet saat ini ada sebanyak 88,1 juta orang dari total populasi penduduk Indonesia yang sebesar 259 juta jiwa. Sementara, 79 juta di antaranya merupakan pengguna media sosial aktif.

E-commerce merupakan perubahan dari pemasaran secara fisik kepada pemasaran digital. Berkembangnya bisnis e-commerce di Indonesia telah merubah beberapa perilaku konsumen salah satunya adalah kebiasan berbelanja di pusat perbelanjaan atau toko sekarang mulai beralih dengan menggunakan media online. Selama terkoneksi dengan internet, konsumen tidak harus mendatangi toko atau tempat perbelanjaan untuk mendapatkan barang atau jasa yang diinginkannya. Dengan beralihnya perliaku konsumen tersebut diharapkan dapat mengefisiensi biaya dan waktu. Mengurangi biaya memang menjadi sangat penting apalagi kalau mengingat aktifitas komersil konvensional seringkali melibatkan beberapa rantai aktifitas yang menimbulkan biaya yang cukup tinggi dan waktu yang tidak sedikit dalam menyelesaikan suatu proses ekonomi. Contoh yang mudah adalah dalam kegiatan sehari-hari, di Jakarta misalnya, jika ingin membeli baju paling tidak harus menyiapkan kendaraan keluar atau menunggu kendaraan umum, melakukan perjalanan dari tempat kediaman menuju ke Mall terdekat, terkena macet lalu lintas Jakarta, mencari tempat parkir, mengeluarkan ongkos parkir, masuk ke Mall, memilih baju yang cocok dan melakukan transaksi pembelian baik kontan maupun dengan kartu kredit. Proses ekonomi diatas memakan waktu, biaya dan tenaga yang tidak kecil.

Dalam ekonomi berbasis e-commerce, dapat digambarkan hanya perlu medial nomor akses ISP, melakukan penelusuran informasi mengenai barang yang diinginkan di virtual mall dengan search engine atau katalog elektronik, dan mengisi formulir pemesanan (form order) dalam waktu kurang dari satu jam maka kita sudah dapat melakukan kegiatan $e$-commerce. Gambaran mengenai $e$ commerce diatas merupakan suatu ulasan mengenai bagaimana, biaya waktu dan tenaga dapat begitu di tekan untuk melakukan kegiatan ekonomi.

Keputusan pembelian merupakan kegiatan individu, kelompok atau organisasi yang terlibat secara langsung dalam pengambilan keputusan membeli produk yang ditawarkan oleh produsen kepada pembeli. Keputusan pembelian sangat ditentukan oleh kepercayaan terhadap rekanan, media atau lainnya yang terlibat dalam suatu kegiatan. Keputusan pembelian dalam e-commerce akan tumbuh dengan baik apabila penjual mampu menjaga kepercayaan yang telah diberikan oleh konsumen. Ketika konsumen merasakan bahwa penjual telah menjaga dengan baik kepercayaan yang diberikan, maka konsumen dengan senang hati akan terus meningkatkan pembelian produknya. Salah satu yang mempengaruhi keputusan pembelian konsumen untuk membeli suatu produk melalui media online adalah kepercayaan. Kepercayaan merupakan salah satu pondasi dari bisnis apapun, suatu transaksi bisnis antara dua belah pihak atau lebih akan terjadi apabila masing-masing pihak saling mempercayai. Kepercayaan ini 
Jurnal Ilmiah Untuk Mewujudkan Masyarakat Madani ISSN 2355-309X

tidak begitu saja dapat diakui oleh pihak lain atau mitra bisnis, melainkan harus dibangun mulai dari awal dan dapat dibuktikan. Kepercayaan merupakan pondasi yang kuat untuk menentukan sukses atau tidaknya $e$ commerce kedepan. Ketika persepsi resiko tinggi maka konsumen akan berfikir apakah akan menghindari pembelian atau meminimumkan risiko melalui pencairan dan evaluasi alternatif lainnya.

Persepsi resiko menunjuk pada rasa ketidakpastian yang dialami oleh konsumen saat memutuskan untuk melakukan pembelian melalui online. Dalam konteks transaksi online, indvidu akan cenderung untuk melihat risiko yang mungkin akan muncul dari transaksi yang akan dilakukan. Karena sifatnya yang tidak bertemu langsung antara pembeli dan penjual, dalam transaksi $e$ commerce akan memunculkan persepsi risiko yang berbeda-beda bagi setiap orang. Kekhawatiran ini biasa terjadi dalam bentuk risiko kehilangan uang, faktor keamanan, faktor waktu pengiriman produk, dan kualitas produk itu sendiri. Kenyaatan ini tentu akan sangat berpengaruh terhadap keputusan pembelian konsumen untuk berbelanja melalui layanan e-commerce, sehingga transaksi melalui media online harus dilakukans secara hati-hati guna meminimalisir berbagai resiko yang dihadapi pembeli.

Dewasa ini, terdapat banyak jenis $e$ commerce yang berkembang di dunia, namun hanya ada beberapa jenis e-commerce yang berkembang di Indonesia. Salah satu jenis $e$ commerce yang saat ini berkembang pesat di Indonesia adalah e-commerce jenis marketplace. Marketplace merupakan sebuah tempat secara daring (dalam jaringan) dimana penjual dapat membuat akun dan menjelaskan barang dagangannya. Salah satu keuntungan berjualan di marketplace adalah penjual tidak perlu membuat situs atau toko online pribadi. Penjual hanya perlu menyediakan foto produk dan mengunggahnya kemudian dilengkapi dengan deskripsi produk tersebut. Selanjutnya, apabila ada pembeli yang ingin membeli produk yang ditawarkan tersebut, pihak penjual akan diberi notifikasi oleh sistem dari e-commerce tersebut. Salah satu jenis marketplace yang cukup populer di
Indonesia adalah Tokopedia.

Tokopedia merupakan online marketplace yang memungkinkan setiap indvidu dan pemilik bisnis di Indonesia membuka dan mengurus toko online mereka secara mudah dan bebas biaya, sekaligus memberikan pengalaman jual beli online secara aman dan nyaman. Kemudahan yang ditawarkan oleh situs Tokopedia.com tidak lepas dari berbagai kemungkinan terjadinya berbagai risiko. Layanannya yang gratis dan terbuka untuk umum ternyata di manfaatkan oleh segelintir pihak untuk melakukan tindak kejahatan. Dari berbagai jenis kejahatan yang ada dalam internet, kejahatan yang sering terjadi melalui situs Tokopedia.com adalah penipuan dengan modus menjual barang fiktif.

Berdasarkan permasalahan dan fenomena tersebut maka penulis pun tertarik untuk melakukan penelitian mengenai kepercayaan dan persepsi risiko bisnis online. Dengan berbagai kasus penipuan dan juga kejahatan-kejahatan online lainnya apakah akan mempengaruhi keputusan pembelian konsumen. Untuk itu penulis akan melakukan penelitian dengan judul "Pengaruh Kepercayaan dan Persepsi Risiko Terhadap Keputusan Pembelian Ecommerce Pada Tokopedia.com Di Jakarta Pusat"

\section{KAJIAN PUSTAKA}

\section{E-Commerce}

a. Pengertian E-commerce

Secara garis besar, perdagangan elekronik (e-commerce) didefinisikan sebagai cara untuk menjual dan membeli barang-barang dan jasa lewat jaringan internet, tetapi hal ini tentu saja mencakup berbagai aspek. Ferraro ( 2008 ) mengatakan bahwa yang dimaksud dengan e-commerce adalah aktivitas penjualan dan pembelian barang atau jasa melalui fasilitas internet. Media yang populer dalam aktivitas e-commerce adalah world wide web (www).

Oleh karenanya, perbaikan terus menerus mengenai pelayanan yang disediakan oleh sistem web e-commerce akan mempunyai pengaruh yang besar pada tingkat penjualan dan kepuasan konsumen. 
Heksawan Rahmadi \& Deni Malik, Pengaruh Kepercayaan Dan Persepsi Risiko ...

Menurut Ustadiyanto ( 2001 : 11) dalam praktiknya, e-commerce dikelompokkan menjadi dua segmen yaitu business to business $(B 2 B)$ dan business to consumer (B2C). B2B e-commerce merupakan bentuk transaksi perdagangan melalui internet yang dilakukan oleh dua atau lebih perusahaan, sedangkan $\mathrm{B} 2 \mathrm{C}$ e-commerce merupakan transaksi jual beli melalui internet antara penjual dengan konsumen. Secara fundamental transaksi business to consumer (B2C) memiliki desain yang berbeda dengan business to business (B2B). Konsumen yang dihadapi dalam transaksi business to consumer (B2C) mungkin memiliki atau tidak memiliki kemampuan dalam mempergunakan teknologi informasi. Oleh karena itu, di dalam web e-commerce untuk keperluan B2C mutlak harus dipasang panduan atau bantuan bagi konsumen yang mengalami kesulitan. Jika dibandingkan dengan B2B, jumlah transaksi B2C lebih besar, tetapi nilai transaksinya lebih kecil.

\section{b. Keuntungan E-commerce}

Perdagangan secara elektronik menawarkan kepada perusahaan keuntungan jangka pendek dan jangka panjang. Beberapa keuntungan perdagangan elektronik bagi perusahaan, konsumen dan masyarakat umum adalah sebagai berikut :

1) Keuntungan Bagi Perusahaan

a) Memperpendek Jarak

Perusahaan-perusahaan dapat lebih mendekatkan diri dengan konsumen. Dengan hanya mengklik link-link yang ada pada situs-situs, konsumen dapat menuju ke perusahaan dimana pun saat itu mereka berada.

b) Perluasan Pasar

Jangkauan pemasaran menjadi semakin luas dan tidak terbatas oleh area geografis dimana perusahaan berada

c) Efisien

Seperti disinggung di bagian sebelumnya, perdagangan elektronik ( $e$ commerce) akan sangat memangkas biaya-biaya operasional.

Perusahaan-perusahaan yang berdagang secara elektronik tidak membutuhkan kantor dan toko yang besar, menghemat kertas-kertas yang digunakan untuk transaksi-transaksi, periklanan, serta pencatatan-pencatatan.

2) Keuntungan Bagi Konsumen

a) Efektif

Konsumen dapat memperoleh informasi tentang produk atau jasa yang dibutuhkannya dan bertransaksi dengan cara yang cepat dan murah.

b) Aman Secara Fisik

Konsumen tidak perlu mendatangi toko atau tempat perusahaan menjajakan barangnya dan ini memungkinkan konsumen dapat bertransaksi dengan aman sebab di daerah-daerah tertentu mungkin sangat berbahaya jika berkendara dan membawa uang tunai dalam jumlah yang besar.

c) Fleksibel

Konsumen dapat melakukan transaksi dari berbagai lokasi, baik dari rumah, kantor, warnet, atau tempat-tempat lainnya. Konsumen juga tidak perlu berdandan rapih seperti konsumen pada perdagangan tradisional umumnya.

3) Keuntungan Bagi Masyarakat Umum

a) Membuka Peluang Kerja Baru

Era perdagangan elektronik akan membuka peluang-peluang kerja baru bagi mereka yang tidak buta teknologi. Muncul pekerjaan-pekerjaan baru seperti pemprograman komputer, perancang web, analisis sistem dan sebagainya.

b) Menguntungkan Dunia Akademis

Berubahnya pola hidup masyarakat dengan hadirnya perdagangan elektronik, kalangan akademisi akan semakin diperkaya dengan kajian-kajian psikologis, antropologis, social-budaya, dan sebagainya. Selain itu, dampak langsung dari hadirnya internet secara langsung akan menantang kiprah ilmuwan di bidang teknik komputer, teknik telekomunikasi, elektronika, pengembangan perangkat lunak dan sebagainya.

c) Meningkatkan Kualitas Sumberdaya Manusia

Perdagangan elektronik, seperti juga teknologi komputer pada umumnya, hanya bisa dilakukan oleh orang-orang yang tidak gagap teknologi (gatek), sehingga pada gilirannya akan 
Jurnal Ilmiah Untuk Mewujudkan Masyarakat Madani

ISSN 2355-309X

merangsang orang-orang untuk mempelajari teknologi komputer demi kepentingan mereka sendiri.

\section{c. Kerugian E-commerce}

Disamping segala hal yang menguntungkan, sesuatu ciptaan manusia pasti memiliki sisi negatif. Namun, dari segi sudut pandang manapun, perdagangan elektronik memiliki segi positif lebih banyak dari sisi negatifnya.

Berikut dibawah ini beberapa segi negatif perdagangan elektronik (e-commerce) adalah sebagai berikut :

1) Tidak Manusiawi

Sering sekali orang pergi ke toko-toko dan pusat-pusat perbelanjaan (mall) tidak sekedar ingin memuaskan kebutuhannya akan barang atau jasa tertentu. Ia mungkin melakukannya untuk penyegaran (refreshing) atau bersosialisasi dengan rekan-rekan atau keluarganya. Perdagangan elektronik gagal dipandang dari sudut pandang seperti ini. Di internet meski kita dapat mengobrol (chatting) dengan orang lain, kita mungkin tidak dapat merasakan jabat tangannya, senyuman ramahnya atau candanya.

2) Meningkatkan Individualisme

Pada perdagangan elektronik, seseorang dapat bertransaksi dan mendapatkan barang atau jasa yang diperlukannya tanpa perlu bertemu dengan siapa pun. Ini yang membuat beberapa orang menjadi berpusat pada diri sendiri serta individualitas dan merasa dirinya tidak terlalu membutuhkan kehadiran orang lain dalam hidupnya.

3) Terkadang Menimbulkan Kekecewaan Apa yang dilihat dilayar monitor komputer atau handphone kadang berbeda dengan apa yang dilihat secara kasat mata.

\section{Kepercayaan}

\section{a. Pengertian Kepercayaan (Trust)}

Yousafzai et al (2003) mendefinisikan kepercayaan sebagai berikut :

"Kepercayaan merupakan pondasi dari bisnis. Suatu transaksi bisnis antara dua pihak atau lebih akan terjadi apabila masingmasing saling mempercayai. Kepercayaan ini tidak begitu saja dapat diakui oleh pihak lain atau mitra bisnis, melainkan harus dibangun mulai dari awal dan dapat dibuktikan. Kepercayaan telah dipertimbangkan sebagai katalis dalam berbagai transaksi antara penjual dan pembeli agar kepuasan konsumen dapat terwujud sesuai dengan yang diharapkan".

Farida Jasfar ( 2009 : 167 ) mengatakan bahwa kepercayaan merupakan perekat yang memungkinkan perusahaan untuk mempercayai orang lain dalam mengorganisir dan menggunakan sumber daya secara efektif dalam menciptakan nilai tambah.

Kepercayaan merupakan pondasi yang kuat untuk menentukan sukses atau tidaknya e-commerce kedepan. Pasalnya ketika seseorang yang ingin melakukan secara online, maka hal utama yang diperhatikan adalah reputasi toko online tersebut apakah dapat dipercaya atau tidak, hal ini bisa dilakukan dengan mengecek testimoni pembeli yang pernah berbelanja di situs tersebut. Konsumen tentu mengharapkan uang yang dikirimkannya tidak hilang begitu saja akan tetapi mendapatkan balasan produk yang diinginkan dan sesuai dengan apa yang ditampilkan dan dijelaskan oleh penjual.

Kepercayaan akan timbul apabila konsumen telah merasakan kepuasan karena telah mengkonsumsi atau menggunakan produk dengan merek tertentu. Konsumen yang merasa nyaman dan percaya karena sebuah produk, tidak akan mudah meninggalkan atau mengganti produk tersebut dengan produk merek lain.

\section{b. Dimensi Kepercayaan}

Menurut Mayer et al. (1995) dalam Rofiq (2007) faktor yang membentuk kepercayaan seseorang terhadap yang lain ada tiga yaitu kemampuan (ability), perbuatan baik (benevolence), dan integritas (integrity).

Ketiga faktor tersebut dapat dijelaskan sebagai berikut :

1) Kemampuan (Ability)

Kemampuan mengacu pada kompetensi dan karakteristik penjual atau organisasi dalam mempengaruhi dan mengotorisasi wilayah yang spesifik. Dalam hal ini, bagaimana penjual mampu menyediakan, melayani, 
Heksawan Rahmadi \& Deni Malik, Pengaruh Kepercayaan Dan Persepsi Risiko ...

sampai mengamankan transaksi dari gangguan pihak lain. Artinya bahwa konsumen memperoleh jaminan kepuasan dan keamanan dari penjual dalam melakukan transaksi.

Kim et al. (2003a) menyatakan bahwa ability meliputi kompetensi, pengalaman, pengesahan institusional, dan kemampuam dalam ilmu pengetahuan.

2) Perbuatan Baik (Benevolence)

Perbuatan baik merupakan kemauan penjual dalam memberikan kepuasan yang saling menguntungkan antara dirinya dengan konsumen. Profit yang diperoleh penjual dapat dimaksimumkan, tetapi kepuasan konsumen juga tinggi.

Penjual bukan semata-mata mengejar profit maksimum, melainkan juga memiliki perhatian yang besar dalam mewujudkan kepuasan konsumen.

Menurut Kim et al. (2003a), benevolence meliputi perhatian, empati, keyakinan, dan daya terima.

3) Integritas (Integrity)

Integritas berkaitan dengan bagaimana perilaku atau kebiasaan penjual dalam menjalankan bisnisnya. Informasi yang diberikan kepada konsumen apakah benar sesuai dengan fakta atau tidak. Kualitas produk yang dijual apakah dapat dipercaya atau tidak.

Kim et al. (2003a) mengemukakan bahwa integrity dapat dilihat dari sudut kewajaran (fairness), pemenuhan (fulfillment), kesetiaan (loyalty), keterusterangan (honestly), keterkaitan (dependability), dan kehandalan (reliabilty).

\section{Persepsi Risiko}

\section{a. Pengertian Persepsi Risiko (Perceived Risk)}

Shiffman dan Kanuk ( 2008 : 102 ) mendefinisikan Persepsi risiko (Perceived risk) adalah ketidakpastian yang dihadapi para konsumen jika mereka tidak dapat meramalkan konsekuensi keputusan pembelian mereka.

Sedangkan menurut Samadi dan Najadi ( 2009 : 89 ), Persepsi risiko adalah keyakinan subjektif individu tentang potensi konsekuensi negative dari keputusan pembelian yang diambil oleh konsumen.

Apabila dilihat dari kedua definisi tersebut, dapat dikatakan bahwa persepsi risiko merupakan ketidakpastian yang dihadapi konsumen yang menimbulkan suatu keyakinan yang subjektif terhadap suatu keputusan yang akan diambilnya.

Persepsi risiko merupakan penyebab utama mengapa orang enggan berbelanja online. Karena sifatnya yang tidak bertemu secara langsung antara pembeli dan penjual, e-commerce memunculkan persepsi risiko yang berbeda beda. Ada yang menghawatirkan kehilangan uang, ada yang menghawatirkan faktor waktu pengiriman, ada juga yang mempertimbangkan faktor keamanan dan privasi (Detiknet,2012).

Engel et.al ( 1995 : 162 ) menegaskan kembali bahwa semakin besar persepsi risiko semakin besar pula kemungkinan keterlibatan konsumen pada pembelian. Ketika persepsi risiko tinggi, konsumen mempunyai pilihan apakah akan menghindari pembelian dan penggunaan atau meminimumkan risiko melalui pencarian dan evaluasi alternatif prapembelian dalam tahap pengambilan keputusan. Kondisi ini menghasilkan pengambilan keputusan yang kompleks. Konsumen mungkin akan mengevaluasi merek secara detail. Informasi mengenai produk sangat dibutuhkan dan konsumen mencoba mengevaluasi berbagai merek. Proses pengambilan keputusan yang demikian menggambarkan adanya keterlibatan konsumen dengan suatu produk.

Sementara itu Assael (1998) menyatakan bahwa persepsi risiko menjadi salah satu komponen penting dalam pemrosesan informasi yang dilakukan oleh konsumen. Konsumen semakin terdorong untuk mencari tambahan informasi ketika dihadapkan pada pembelian produk dengan risiko tinggi. Risiko persepsian menjadi lebih tinggi ketika (1) Sedikit tersedia informasi mengegnai produk ; (2) Produk tersebut merupakan produk baru ; (3) Produk tersebut memiliki produk yang kompleks (4) Rendahnya kepercayaan diri konsumen untuk mengevaluasi merek (5) Tingginya harga produk (6) Produk tersebut penting bagi 
Jurnal Ilmiah Untuk Mewujudkan Masyarakat Madani ISSN 2355-309X

konsumen.

Ketika persepsi risiko menjadi tinggi, ada motivasi apakah akan menghindari menggunakan produk/jasa atau meminimumkan risiko melalui pencarian dan evaluasi alternatif pra-pembelian dalam tahap pengambilan keputusan.

\section{b. Dimensi Persepsi Risiko}

Menurut Mulyadi Nitisusastro (2012) dalam Pebri Rochmawati (2015) dimensi persepsi risiko adalah sebagai berikut :

1) Risiko Keuangan (Financial Risk)

Risiko yang berkaitan dengan kekhawatiran akan menghadapi kesulitan dalam hal dana.

2) Risiko Sosial (Social Risk)

Risiko ini terkait dengan dampak negative yang datang dari lingkungannya apabila ia membeli dan mengkonsumsi barang tersebut.

3) Risiko Fungsional (Performance Risk)

Risiko tentang fungsi berkaitan dengan dampak negative yang akan timbul apabila konsumen mengetahui dan memahami banyak produk yanga kan dibeli tersebut mengandung sejumlah keburukan apabila dibeli dan dikonsumsi.

4) Risiko Waktu (Time Risk)

Risiko bahwa sebuah keputusan akan menghabiskan banyak waktu.

5) Risiko Fisik (Phsycal Risk)

Risiko ini terkait dengan kekhawatiran konsumen bahwa suatu produk dapat menyebabkan suatu bahaya fisik tertentu.

6) Risiko Psikologis (Psychological Risk)

Risiko ini terkait dengan terjadinya dampak negative akan melekat pada dirinya apabila ia membeli dan mengkonsumsi barang tersebut.

\section{Keputusan Pembelian}

\section{a. Pengertian Keputusan Pembelian (Purchase Decision)}

Keputusan pembelian merupakan suatu bagian pokok dalam perilaku konsumen yang mengarah kepada pembelian produk atau jasa. Dalam membuat sebuah keputusan pembelian, konsumen tidak terlepas dari faktor-faktor yang mempengaruhi dan memotivasi konsumen untuk mengadakan pembelian. Dari faktor-faktor inilah, maka konsumen akan melakukan penilaian terhadap berbagai alternatif pilihan dan memilih salah satu atau lebih alternatif yang diperlukan berdasarkan pertimbanganpertimbangan tertentu. Berikut beberapa pendapat ahli mengenai pengertian dari keputusan pembelian.

Menurut Amirullah ( 2002 : 62 ), berpendapat bahwa keputusan pembelian adalah proses dimana konsumen melakukan penilaian terhadap berbagai alternatif pilihan dan memilih salah satu atau lebih alternatif yang diperlukan berdasarkan pertimbanganpertimbangan tertentu. Sedangkan Philip Kotler ( 2007 : 223 ) berpendapat bahwa yang dimaksud dengan keputusan pembelian adalah sebagai berikut :"Keputusan pembelian yaitu beberapa tahapan yang dilakukan oleh konsumen sebelum melakukan keputusan pembelian suatu produk. Setiap konsumen dalam melakukan keputusan pembelian tentu selalu didasari oleh faktor-faktor yang sangat penting, baik dari dalam maupun dari luar pribadinya untuk memastikan keputusan pembelian itu".

\section{b. Dimensi Keputusan Pembelian}

Menurut Kotler dan Amstrong ( 2004 : 224 ) dalam Ainun Fika (2015), keputusan pembelian oleh konsumen secara umum dipengaruhi oleh faktor-faktor sebagai berikut

1) Pengenalan kebutuhan (need recognition) Pengenalan kebutuhan (need recognition) yaitu pembeli mengenali masalah atau kebutuhan. Tahap ini sedikit banyak dipengaruhi oleh bagaimana pengetahuan konsumen akan pembelian.

Dimensi dasar dari pengenalan kebutuhan melibatkan informasi berkenaan dengan keputusan tentang dimana produk tersebut harus dibeli dan kapan pembelian harus terjadi.

2) Pencarian informasi (information research)

Pencarian informasi (information research) yaitu tahap proses pengambilan keputusan pembeli dimana konsumen telah tertarik untuk mencari lebih banyak informasi. Pada tahap ini seorang yang tertarik akan suatu produk mungkin akan mencari lebih banyak informasi. Jika dorongan konsumen begitu kuat dan 
Heksawan Rahmadi \& Deni Malik, Pengaruh Kepercayaan Dan Persepsi Risiko ...

produk yang memuaskan berada dalam jangkauan, konsumen kemungkinan besar akan melakukan pembelian.

3) Evaluasi berbagai alternatif (alternative evaluation)

Evaluasi berbagai alternatif (alternative evaluation) yaitu tahap dalam proses pengambilan keputusan pembeli dimana konsumen menggunakan informasi untuk mengevaluasi merekmerek alternatif dalam satu susunan pilihan.

4) Keputusan pembelian (purchase decision)

Keputusan pembelian (purchase decision) yaitu tahap dalam proses pengambilan keputusan pembeli dimana konsumen benar-benar membeli produk.

5) Perilaku pasca pembelian (postpurchase behaviour)
Perilaku pasca pembelian (postpurchase behaviour) yaitu tahap dalam proses pengambilan keputusan pembeli dimana konsumen mengambil tindakan lebih lanjut setelah membeli berdasarkan kepuasan yang mereka rasakan. Untuk itu dapat dilakukan pengukuran melalui perekomendasian kepada calon pembeli selanjutnya dan perasaan puas dengan pengalaman belanja sebelumnya.

Menurut Kotler dan Armstrong ( 2004 : 224 ) yang menentukan puas atau tidak puasnya pembelian terletak pada hubungan antara harapan konsumen dan kinerja produk yang dirasakan.

Tahap-tahap pengambilan keputusan pembelian di atas dapat digambarkan sebagai berikut :

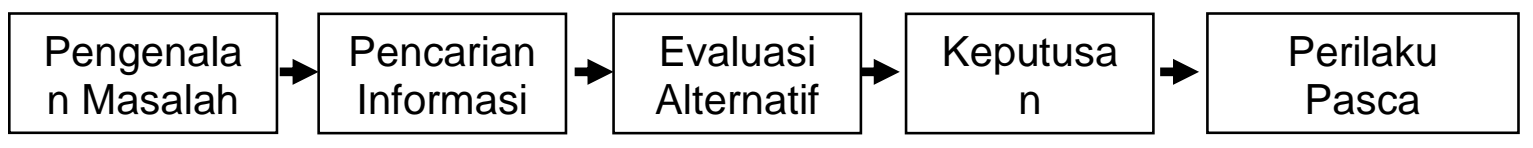

\section{Kerangka Teori
\[ \begin{array}{l}\text { KEPERCAYAAN }\left(\mathbf{X}_{\mathbf{1}}\right) \\ \text { 1. Kemampuan } \\ \text { 2. Perbuatan Baik } \\ \text { 3. Integritas } \\ \text { Sumber : Mayer at al (1995) }\end{array} \] dalam Rofiq (2007)}

\section{PERSEPSI RISIKO $\left(\mathrm{X}_{2}\right)$}

1. Risiko Keuangan

2. Risiko Sosial

3. Risiko Fungsional

4. Risiko Waktu

5. Risiko Fisik

6. Risiko Psikologis

Sumber : Mulyadi Nitisusatro (2012) dalam Rochmawati

(mn15)
I

\section{Hipotesis}

Arikunto ( 2006 : 71 ) mendifiniskan hipotesis sebagai berikut :
"Hipotesis berasal dari dua penggalan kata yaitu "hypo" yang artinya "di bawah" dan "thesa" yang artinya "kebenaran". Hipotesis 
Jurnal Ilmiah Untuk Mewujudkan Masyarakat Madani ISSN 2355-309X

dapat diartikan sebagai jawaban yang bersifat sementara terhadap permasalahan penelitian, sampai terbukti melalui data yang terkumpul".

Sedangkan menurut Sugiyono ( 2014 : 134 ) yang dimaksud hipotesis yaitu :

"Hipotesis adalah jawaban sementara terhadap rumusan masalah penelitian telah dinyatakan dalam bentuk pertanyaan. Dikatakan sementara karena jawaban yang diberikan baru didasarkan pada teori”.

Untuk itu pada penelitian ini penulis merumuskan hipotesis penelitian sebagai berikut :
$\mathrm{H}_{1} \quad$ Diduga terdapat pengaruh yang signifkan antara kepercayaan terhadap keputusan pembelian e-commerce pada Tokopedia.com di Jakarta Pusat.

$\mathrm{H}_{2}$ Diduga terdapat pengaruh yang signifkan antara persepsi risiko terhadap keputusan pembelian e-commerce pada Tokopedia.com di Jakarta Pusat.

$\mathrm{H}_{3}$ Diduga terdapat pengaruh yang signifkan antara kepercayaan dan persepsi risiko secara bersama-sama terhadap keputusan pembelian e-commerce pada Tokopedia.com di Jakarta Pusat.

Kisi-Kisi Instrumen Penelitian

\begin{tabular}{|c|c|c|c|c|}
\hline No. & Variabel & Dimensi & Indikator & $\begin{array}{l}\text { No. } \\
\text { Item }\end{array}$ \\
\hline \multirow{6}{*}{1} & \multirow{5}{*}{$\begin{array}{l}\text { Kepercayaan } \\
\text { (X1) }\end{array}$} & \multirow{2}{*}{ 1. Kemampuan (Ability) } & a. Kompetensi & 1 \\
\hline & & & b. Pengalaman & 2 \\
\hline & & \multirow{2}{*}{$\begin{array}{l}\text { 2. Perbuatan Baik } \\
\text { (Benevolance) }\end{array}$} & a. Perhatian & 3 \\
\hline & & & b. Empati & 4 \\
\hline & & \multirow[b]{2}{*}{ 3. Integritas (Integrity) } & a. Kesetiaan & 5 \\
\hline & $\begin{array}{l}\text { Mayer et al } \\
\text { (1995) dalam } \\
\text { Rofiq (2007) }\end{array}$ & & b. Keterusterangan & 6 \\
\hline \multirow{9}{*}{2} & \multirow{9}{*}{$\begin{array}{l}\text { Persepsi Risiko } \\
\text { (X2) }\end{array}$} & $\begin{array}{l}\text { 1. Risiko keuangan } \\
\text { (financial risk) }\end{array}$ & a. Kehilangan uang & 7 \\
\hline & & $\begin{array}{l}\text { 2. Risiko social (social } \\
\text { risk) }\end{array}$ & $\begin{array}{l}\text { a. Pandangan negatif dari lingkungan } \\
\text { social }\end{array}$ & 8 \\
\hline & & \multirow{2}{*}{$\begin{array}{l}\text { 3. Risiko kinerja } \\
\text { (performance risk) }\end{array}$} & a. Kesesuain produk yang dipesan & 9 \\
\hline & & & b Rasa kekecewaan & 10 \\
\hline & & $\begin{array}{l}\text { 4. Risiko waktu (time } \\
\text { risk) }\end{array}$ & a. Lama waktu pengiriman & 11 \\
\hline & & \multirow{2}{*}{$\begin{array}{l}\text { 5. Risiko fisik (phsyical } \\
\text { risk) }\end{array}$} & a. Kekhawatiran keamanan produk & 12 \\
\hline & & & b Tidak ada penjaminan produk & 13 \\
\hline & & \multirow{2}{*}{$\begin{array}{l}\text { 6. Risiko psikologis } \\
\text { (psychological risk) }\end{array}$} & a Ketidakpastian penjaminan informasi & 14 \\
\hline & & & b.Tidak nyaman secara psikologis & 15 \\
\hline \multirow{6}{*}{3} & \multirow{3}{*}{$\begin{array}{c}\text { Keputusan } \\
\text { Pembelian (Y) }\end{array}$} & $\begin{array}{l}\text { 1. Pengenalan kebutuhan } \\
\text { (Need Recognition) }\end{array}$ & a. Kebutuhan produk & 16 \\
\hline & & $\begin{array}{l}\text { 2. Pencarian informasi } \\
\text { (Search Information) }\end{array}$ & a. Pemberian informasi yang jelas & 17 \\
\hline & & $\begin{array}{l}\text { 3. Evaluasi alternatif } \\
\text { (Alternative Evaluation) }\end{array}$ & $\begin{array}{l}\text { a. Produk yang bervariasi dan banyak } \\
\text { pilihan }\end{array}$ & 18 \\
\hline & \multirow{3}{*}{$\begin{array}{l}\text { Kotler dan } \\
\text { Amstrong } \\
\text { (2004) dalam } \\
\text { Ainun Fika } \\
\text { (2015) }\end{array}$} & $\begin{array}{l}\text { 4. Keputusan pembelian } \\
\text { (Purchase Decision) }\end{array}$ & $\begin{array}{l}\text { a. Konsumen benar-benar membeli } \\
\text { produk }\end{array}$ & 19 \\
\hline & & \multirow{2}{*}{$\begin{array}{l}\text { 5. Perilaku setelah } \\
\text { pembelian } \\
\text { (Post-purchase behavior) }\end{array}$} & $\begin{array}{l}\text { b Perekomendasian kepada calon } \\
\text { pembeli }\end{array}$ & 20 \\
\hline & & & $\begin{array}{l}\text { e. Perasaan puas setelah membeli } \\
\text { produk }\end{array}$ & 21 \\
\hline
\end{tabular}


Heksawan Rahmadi \& Deni Malik, Pengaruh Kepercayaan Dan Persepsi Risiko ...

Teknik Pengumpulan Data, Populasi dan Sample

Tipe pertanyaan pada kuesioner ini adalah pertanyaan tertutup (closed question). Penyebaran kuesioner digunakan untuk mendapatkan data kuantitatif yang terdiri dari variabel bebas dan variabel terikat. Adapun untuk teknik pengukurannya menggunakan skala likert.

Dalam penelitian ini populasinya adalah seluruh pengguna Tokopedia (toppers) di Jakarta Pusat. Dalam penelitian ini teknik Hasil Penelitian

\section{a. Rekapitulasi Tanggapan Responden Terhadap Persepsi Risiko $\left(\mathrm{X}_{2}\right)$}

Tabel IV.22 Rekapitulasi Terhadap Persepsi Risiko $\left(\mathbf{X}_{2}\right)$

\begin{tabular}{|c|l|c|c|}
\hline No & \multicolumn{1}{|c|}{ Pernyataan } & Nilai & Kategori \\
\hline 7 & $\begin{array}{l}\text { Saya merasa bahwa berbelanja di situs Tokopedia.com akan } \\
\text { berisiko kehilangan uang. }\end{array}$ & $3,30^{*}$ & Cukup Baik \\
\hline 8 & $\begin{array}{l}\text { Saya merasa ada risiko tertentu yang harus saya tanggung } \\
\text { dalam melakukan aktifitas online shopping di situs } \\
\text { Tokopedia.com akibat cerita orang lain. }\end{array}$ & $3,15^{*}$ & Cukup Baik \\
\hline 9 & $\begin{array}{l}\text { Saya takut produk yang saya pesan tidak sesuai dengan } \\
\text { gambar. }\end{array}$ & 3,48 & Baik \\
\hline 10 & $\begin{array}{l}\text { Saya merasa bahwa bertransaksi di Tokopedia.com akan } \\
\text { menimbulkan kekecewaan karena ketidaksesuaian produk }\end{array}$ & 3,52 & Baik \\
\hline 11 & $\begin{array}{l}\text { Saya merasa bahwa berbelanja di situs Tokopedia.com } \\
\text { membutuhkan waktu pengiriman yang lama. }\end{array}$ & 3,47 & Baik \\
\hline 12 & $\begin{array}{l}\text { Saya merasa transaksi di situs Tokopedia.com belum tentu } \\
\text { memiliki keamanan yang tinggi. }\end{array}$ & $3,38^{*}$ & Cukup Baik \\
\hline 13 & $\begin{array}{l}\text { Saya merasa situs Tokopedia.com belum tentu dapat } \\
\text { menjamin setiap kebutuhan konsumen dalam melakukan } \\
\text { transaksi. }\end{array}$ & $3,25^{*}$ & Cukup Baik \\
\hline 14 & $\begin{array}{l}\text { Saya merasa terlalu banyak ketidakpastian seandainya } \\
\text { memberikan informasi pribadi pada penjual di } \\
\text { Tokopedia.com }\end{array}$ & $3,24^{*}$ & Cukup Baik \\
\hline 15 & $\begin{array}{l}\text { Saya merasa dengan memberikan informasi kepada situs } \\
\text { Tokopedia.com akan menimbulkan banyak permasalahan } \\
\text { yang tak terduga. }\end{array}$ & $\mathbf{3 0 , 0 7}$ \\
\hline & \begin{tabular}{l} 
Cukup Baik \\
\hline
\end{tabular} & $3,28^{*}$ (Cukup Baik) \\
\hline
\end{tabular}

Sumber : data primer hasil kuesioner

Berdasarkan tabel IV.22 diatas diketahui bahwa hasil rekapitulasi tanggapan responden terhadap persepsi risiko sebesar 3,34 yang yang digunakan adalah sampling purposive yang termasuk dalam metode nonprobability sampling. Jumlah sampel yang ditetapkan adalah sebanyak 105 sampel. Hal ini sesuai dengan rekomendasi dari Hair et al. (2006) dalam Mulyana (2016) yang merekomendasikan jumlah sampel data observasi minimal 5 kali parameter yang akan diestimasi atau minimal 100. Dalam penelitian ini terdapat 21 item pertanyaan dari indikator dependen dan independen. Jadi minimal sampel yang harus di ambil adalah sebesar 5 x $21=105$ sampel. 
Jurnal Ilmiah Untuk Mewujudkan Masyarakat Madani

ISSN 2355-309X

mendapatkan responden paling rendah yaitu dimensi risiko sesial (socail risk) dalam

indikator pandangan negatif dari lingkungan sosial.

\section{b. Rekapitulasi Tanggapan Responden Terhadap Keputusan Pembelian (Y)}

Tabel IV.29 Rekapitulasi Terhadap Keputusan Pembelian (Y)

\begin{tabular}{|c|l|c|c|}
\hline No & \multicolumn{1}{|c|}{ Pernyataan } & Nilai & Kategori \\
\hline 16 & $\begin{array}{l}\text { Saya memutuskan untuk melakukan pembelian di } \\
\text { Tokopedia.com karena produk yang ditawarkan sesuai } \\
\text { dengan kebutuhan saya. }\end{array}$ & 3,73 & Baik \\
\hline 17 & $\begin{array}{l}\text { Saya memutuskan untuk melakukan pembelian di } \\
\text { Tokopedia.com karena pencarian informasi produknya jelas. }\end{array}$ & 3,65 & Baik \\
\hline 18 & $\begin{array}{l}\text { Saya merasa di Tokopedia.com memiliki banyak pilihan } \\
\text { produk yang membuat saya tertarik untuk melakukan } \\
\text { pembelian. }\end{array}$ & 3,60 & Baik \\
\hline 19 & $\begin{array}{l}\text { Saya memutuskan pembelian untuk membeli produk di } \\
\text { Tokopedia.com karena sesuai dengan apa yang saya } \\
\text { inginkan. }\end{array}$ & 3,66 & Baik \\
\hline 20 & $\begin{array}{l}\text { Saya merekomendasikan orang lain untuk melakukan } \\
\text { pembelian di Tokopedia.com. }\end{array}$ & Cukup Baik \\
\hline 21 & $\begin{array}{l}\text { Saya melakukan pembelian karena puas dengan pengalaman } \\
\text { belanja teman atau keluarga sebelumnya di Tokopedia.com }\end{array}$ & $3,48^{*}$ & Baik \\
\hline \multicolumn{2}{|c|}{ Total Nilai } & $\mathbf{2 1 , 3 9}$ \\
\hline
\end{tabular}

Sumber : data primer hasil kuesioner

Berdasarkan tabel IV.29 diatas diketahui bahwa hasil rekapitulasi tanggapan responden terhadap keputusan pembelian sebesar 3,56 yang dimana berada dalam kategori baik $(3,41$ $-4,20)$. Namun terdapat salah satu indikator yang dimana hasilnya dikatakan mendapatkan responden paling rendah yaitu dimensi perilaku setelah pembelian (post-purchase behavior) dalam indikator perekomendasian kepada calon pembeli.

\section{a. Uji Validitas dan Uji Reliabilitas}

1) Uji Validitas

Untuk penelitian ini telah dilakukan uji validitas menggunakan program SPSS 22 dan telah dilakukan pula uji instrumen penelitiannya terhadap 30 responden. Dibawah ini disajikan tabel hasil validitas dari 105 responden yang sudah sesuai dengan kriteria utama dalam penentuan sampel.

\section{Hasil Uji Statistik}

Tabel IV.30 Hasil Uji Validitas Variabel Kepecyaan $\left(\mathbf{X}_{1}\right)$ Item-Total Statistics

\begin{tabular}{|l|r|r|r|r|}
\hline & $\begin{array}{c}\text { Scale Mean if Item } \\
\text { Deleted }\end{array}$ & $\begin{array}{c}\text { Scale Variance if } \\
\text { Item Deleted }\end{array}$ & $\begin{array}{c}\text { Corrected Item- } \\
\text { Total Correlation }\end{array}$ & $\begin{array}{c}\text { Cronbach's Alpha if } \\
\text { Item Deleted }\end{array}$ \\
\hline X1_1 & 17,50 & 6,156 &, 463 &, 701 \\
X1_2 & 17,64 & 6,349 &, 495 &, 693 \\
X1_3 & 17,74 & 6,058 &, 517 &, 685 \\
X1_4 & 17,68 & 5,933 &, 539 &, 678 \\
X1_5 & 17,72 & 6,625 &, 380 &, 723 \\
X1_6 & 17,57 & 6,209 &, 436 &, 709 \\
\hline
\end{tabular}

Sumber : data diolah dengan SPSS versi 22 
Heksawan Rahmadi \& Deni Malik, Pengaruh Kepercayaan Dan Persepsi Risiko ...

Nilai r-tabel dapat diperoleh melalui $\mathrm{df}($ degree of freedom $)=\mathrm{n}-2$, dimana $\mathrm{k}$ merupakan butir pertanyaan dalam suatu variabel, dan $\mathrm{n}$ merupakan jumlah responden. Maka df $=105-2=103$. Tabel $\mathrm{r}$ product-moment two tailed test (lihat di lampiran) menunjukkan bahwa pada df 103 dengan alpha 5\%, diperoleh $\mathrm{r}$ table sebesar 0,191. Dari hasil di atas dapat disimpulkan sebagai berikut :

(1) $r_{\text {hitung }} \mathrm{P} 1$ sebesar $0,463>\mathrm{r}$ table 0,191, kesimpulan valid

(2) $\mathrm{r}_{\text {hitung }} \mathrm{P} 2$ sebesar 0,495 $>\mathrm{r}$ table 0,191, kesimpulan valid
(3) $\mathrm{r}$ hitung P3 sebesar 0,517 > r table 0,191, kesimpulan valid

(4) $r_{\text {hitung }}$ P4 sebesar 0,539 > $r_{\text {table }}$ 0,191 , kesimpulan valid

(5) $\mathrm{r}_{\text {hitung }}$ P5 sebesar 0,380 > $\mathrm{r}_{\text {table }}$ 0,191, kesimpulan valid

(6) $\mathrm{r}$ hitung P6 sebesar 0,436>r table 0,191, kesimpulan valid

Berdasarkan hasil perhitungan ini, dapat disimpulkan 6 butir pertanyaan variabel memiliki $r_{\text {hitung yang lebih besar }}$ dari nilai $\mathrm{r}$ table, yang berarti bahwa seluruh butir pertanyaan telah valid.

Tabel IV.31 Hasil Uji Validitas Variabel Persepsi Risiko $\left(\mathbf{X}_{2}\right)$ Item-Total Statistics

\begin{tabular}{|l|r|r|r|r|}
\hline & $\begin{array}{c}\text { Scale Mean if Item } \\
\text { Deleted }\end{array}$ & $\begin{array}{c}\text { Scale Variance if } \\
\text { Item Deleted }\end{array}$ & $\begin{array}{c}\text { Corrected Item- } \\
\text { Total Correlation }\end{array}$ & $\begin{array}{c}\text { Cronbach's Alpha if } \\
\text { Item Deleted }\end{array}$ \\
\hline X2_7 & 26,78 & 29,115 &, 422 &, 770 \\
X2_8 & 26,94 & 29,074 &, 457 &, 766 \\
X2_9 & 26,60 & 27,050 &, 608 &, 744 \\
X2_10 & 26,56 & 29,133 &, 454 &, 766 \\
X2_11 & 26,61 & 29,760 &, 368 &, 778 \\
X2_12 & 26,71 & 28,571 &, 467 &, 764 \\
X2_13 & 26,83 & 26,643 &, 623 &, 741 \\
X2_14 & 26,84 & 27,175 &, 611 &, 744 \\
X2_15 & 26,81 & 30,771 &, 244 &, 797 \\
\hline
\end{tabular}

Sumber: Data diolah dengan SPSS 22

Nilai r-tabel dapat diperoleh melalui $\mathrm{df}($ degree of freedom $)=\mathrm{n}-2$, dimana $\mathrm{k}$ merupakan butir pertanyaan dalam suatu variabel, dan $\mathrm{n}$ merupakan jumlah responden. Maka df $=105-2=103$. Tabel $\mathrm{r}$ product-moment two tailed test (lihat di lampiran) menunjukkan bahwa pada df 103 dengan alpha 5\%, diperoleh $\mathrm{r}$ table sebesar 0,191. Dari hasil di atas dapat disimpulkan sebagai berikut :

(1) $\mathrm{r}$ hitung P7 sebesar 0,422 > r table 0,191, kesimpulan valid

(2) $\mathrm{r}$ hitung P8 sebesar $0,457>\mathrm{r}$ table 0,191, kesimpulan valid

(3) $\mathrm{r}_{\text {hitung }}$ P9 sebesar $0,608>\mathrm{r}$ table 0,191, kesimpulan valid
(4) $\mathrm{r}$ hitung P10 sebesar 0,454 > r table 0,191, kesimpulan valid

(5) $\mathrm{r}$ hitung $\mathrm{P} 11$ sebesar 0,368 $>\mathrm{r}$ table 0,191, kesimpulan valid

(6) $\mathrm{r}_{\text {hitung }} \mathrm{P} 12$ sebesar $0,467>\mathrm{r}$ table 0,191, kesimpulan valid

(7) $r$ hitung P13 sebesar 0,623>r table 0,191, kesimpulan valid

(8) $\mathrm{r}$ hitung P14 sebesar 0,611 > $\mathrm{r}$ table 0,191, kesimpulan valid

(9) $\mathrm{r}$ hitung P15 sebesar 0,244 > r table 0,191 , kesimpulan valid

Berdasarkan hasil perhitungan ini, dapat disimpulkan 9 butir pertanyaan variabel memiliki $r_{\text {hitung }}$ yang lebih besar dari nilai $\mathrm{r}$ table, yang berarti bahwa seluruh butir pertanyaan telah valid. 
Tabel IV.32 Hasil Uji Validitas Variabel Keputusan Pembelian (Y) Item-Total Statistics

\begin{tabular}{|l|r|r|r|r|}
\hline & $\begin{array}{c}\text { Scale Mean if } \\
\text { Item Deleted }\end{array}$ & $\begin{array}{c}\text { Scale Variance if } \\
\text { Item Deleted }\end{array}$ & $\begin{array}{c}\text { Corrected Item- } \\
\text { Total Correlation }\end{array}$ & $\begin{array}{c}\text { Cronbach's Alpha if } \\
\text { Item Deleted }\end{array}$ \\
\hline Y_16 & 17,69 & 8,429 &, 451 &, 726 \\
Y_17 & 17,76 & 8,625 &, 726 &, 675 \\
Y_18 & 17,82 & 9,650 &, 268 &, 768 \\
Y_19 & 17,75 & 7,996 &, 534 &, 702 \\
Y_20 & 18,14 & 8,835 &, 354 &, 754 \\
Y_21 & 17,93 & 7,005 &, 712 &, 643 \\
\hline
\end{tabular}

Sumber: Data diolah dengan SPSS 22

Nilai r-tabel dapat diperoleh melalui $\mathrm{df}($ degree of freedom $)=\mathrm{n}-2$, dimana $\mathrm{k}$ merupakan butir pertanyaan dalam suatu variabel, dan $\mathrm{n}$ merupakan jumlah responden. Maka df $=105-2=103$. Tabel $\mathrm{r}$ product-moment two tailed test (lihat di lampiran) menunjukkan bahwa pada df 103 dengan alpha 5\%, diperoleh $\mathrm{r}$ table sebesar 0,191. Dari hasil di atas dapat disimpulkan sebagai berikut:

(1) $\mathrm{r}$ hitung P16 sebesar 0,451> $\mathrm{r}$ table 0,191, kesimpulan valid

(2) $\mathrm{r}_{\text {hitung }} \mathrm{P} 17$ sebesar $0,726>\mathrm{r}$ table 0,191, kesimpulan valid

(3) $r_{\text {hitung }}$ P18 sebesar 0,268> $r$ table 0,191, kesimpulan valid

(4) $r$ hitung P19 sebesar 0,534 > r table 0,191, kesimpulan valid

(5) $\mathrm{r}$ hitung P20 sebesar 0,354 > $\mathrm{r}$ table 0,191, kesimpulan valid

(6) $r$ hitung $\mathrm{P} 21$ sebesar $0,712>\mathrm{r}$ table 0,191, kesimpulan valid

Berdasarkan hasil perhitungan ini, dapat disimpulkan 6 butir pertanyaan variabel memiliki $r_{\text {hitung yang lebih besar }}$ dari nilai $\mathrm{r}$ table, yang berarti bahwa seluruh butir pertanyaan telah valid.

\section{2) Uji Realibilitas}

Untuk menguji reliabilitas instrumen digunakan koefisien reliability Alpha Cronbach yang perhitungannya menggunakan prosedur reliabilitas dengan program SPSS for Windows Versi 22. Tujuannya adalah untuk menilai kestabilan ukuran dan konsistensi responden dalam menjawab kuesioner. Jika nilai cronbach alpha lebih besar dari 0,60 maka kuesioner dapat dikatakan memenuhi konsep reliabilitas, sedangkan jika nilai cronbach alpha lebih kecil dari 0,60 maka kuesioner tidak memenuhi konsep reliabilitas sehingga pertanyaan tidak dapat dijadikan sebagai alat ukur penelitian. Berdasarkan data yang dikumpulkan dari kuesioner penelitian, berikut disajikan hasil uji reliabilitas untuk variabel kepercayaan $\left(\mathrm{X}_{1}\right)$ dalam penelitian ini :

Tabel IV.33 Hasil Uji Reliabilitas Variabel Kepercayaan $\left(\mathbf{X}_{1}\right)$ Reliability Statistics

\begin{tabular}{|lr|l|}
\hline \multicolumn{2}{|l|}{ Cronbach's Alpha } & N of Items \\
\hline &, 735 & \\
\hline
\end{tabular}

Sumber: Data diolah dengan SPSS 22

Berdasarkan tabel di atas dapat disimpulkan bahwa reliabilitas konstruk jawaban atas pertanyaan dan konsisten di jawaban dari butir-butir pertanyaan pada variabel kepercayaan responden tersebut sudah baik. Hal ini dapat dibuktikan dengan melihat nilai Cronbach' Alpha sebesar $0,735>$ dari 0,60 , yang berarti bahwa seluruh jawaban pertanyaan yang mewakili variabel kepercayaan telah reliabel. 
Heksawan Rahmadi \& Deni Malik, Pengaruh Kepercayaan Dan Persepsi Risiko ...

Tabel IV.34 Hasil Uji Reliabilitas Variabel Persepsi Risiko $\left(\mathbf{X}_{2}\right)$ Reliability Statistics

\begin{tabular}{|r|rr|}
\hline \multicolumn{2}{|l|}{ Cronbach's Alpha } & N of Items \\
\hline
\end{tabular}

Sumber: Data diolah dengan SPSS 22

Berdasarkan tabel di atas dapat disimpulkan bahwa reliabilitas konstruk jawaban atas pertanyaan dan konsisten di jawaban dari butir-butir pertanyaan pada variabel persepsi risiko responden tersebut sudah baik. Hal ini dapat dibuktikan dengan melihat nilai Cronbach' Alpha sebesar 0,785 > dari 0,60 , yang berarti bahwa seluruh jawaban pertanyaan yang mewakili variabel persepsi risiko telah reliabel.

\section{Tabel IV.35 Hasil Uji Reliabilitas Keputusan Pembelian (Y)}

Reliability Statistics

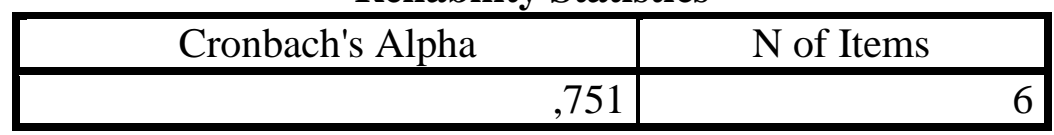

Sumber: Data diolah dengan SPSS 22

Berdasarkan tabel di atas dapat disimpulkan bahwa reliabilitas konstruk jawaban atas pertanyaan dan konsisten di jawaban dari butir-butir pertanyaan pada variabel keputusan pembelian responden tersebut sudah baik. Hal ini dapat dibuktikan dengan melihat nilai Cronbach' Alpha sebesar 0,751 > dari 0,60 , yang berarti bahwa seluruh jawaban pertanyaan yang mewakili variabel keputusan pembelian telah reliabel.
Perhitungan regresi linier sederhana digunakan untuk memprediksi besarnya hubungan antara variabel bebas (independen) yaitu kepercayaan $\left(\mathrm{X}_{1}\right)$ dengan variabel terikat (dependen) yaitu keputusan pembelian (Y), serta variabel bebas (independen) yaitu persepsi risiko (X2) dengan variabel terikat (dependen) yaitu keputusan pembelian (Y).

Hasil regresi linier sederhana dapat dilihat di bawah ini :

\section{3) Analisis Regresi Linier Sederhana}

\section{Tabel IV.36 Hasil Uji Regresi Linier Sederhana ( $X_{1}$ terhadap Y) Coefficients $^{\mathrm{a}}$}

\begin{tabular}{|c|c|c|c|c|c|}
\hline \multirow[b]{2}{*}{ Model } & \multicolumn{2}{|c|}{$\begin{array}{c}\text { Unstandardized } \\
\text { Coefficients }\end{array}$} & \multirow{2}{*}{\begin{tabular}{|c|}
$\begin{array}{c}\text { Standardized } \\
\text { Coefficients }\end{array}$ \\
Beta
\end{tabular}} & \multirow[b]{2}{*}{$\mathrm{t}$} & \multirow[b]{2}{*}{ Sig. } \\
\hline & B & Std. Error & & & \\
\hline (Constant) & 12,341 & 2,281 & & 5,409 &, 000 \\
\hline Kepercayaan & ,429 & ,107 & ,368 & 4,017 & , 000 \\
\hline
\end{tabular}

a. Dependent Variable: Keputusan_Pembelian

\section{Sumber: Data diolah dengan SPSS 22}

Dari perhitungan di atas, diperoleh nilai persamaan regresi linier sederhana sebagai berikut :

$$
\hat{\mathrm{Y}}=12,341(\mathrm{a})+0.429\left(\mathrm{X}_{1}\right)
$$

Berdasarkan persamaan garis regresi tersebut dapat diinterpretasikan sebagai berikut :

(1) Nilai konstanta (a) 
REFORMASI ADMINISTRASI

Jurnal Ilmiah Untuk Mewujudkan Masyarakat Madani

ISSN 2355-309X

Nilai a sebesar 12,341, hal ini menunjukkan apabila tidak ada kepercayaan $(\mathrm{X}=0)$, maka perkiraan keputusan pembelian diperoleh sebesar 12,341.

(2) Pengaruh kepercayaan $\left(\mathrm{X}_{1}\right)$ terhadap keputusan pembelian $(\mathrm{Y})$
Volume 3, No. 1, Maret 2016

Nilai b sebesar 0.429 , menunjukkan bahwa pengaruh kepercayaan bersifat positif, dan hal ini menjelaskan bahwa setiap perubahan kepercayaan sebesar 1 satuan akan meningkatkan keputusan pembelian sebesar 0.429 .

Tabel IV.37 Hasil Uji Regresi Linier Sederhana ( $\mathbf{X}_{2}$ terhadap $\left.Y\right)$ Coefficients $^{\mathrm{a}}$

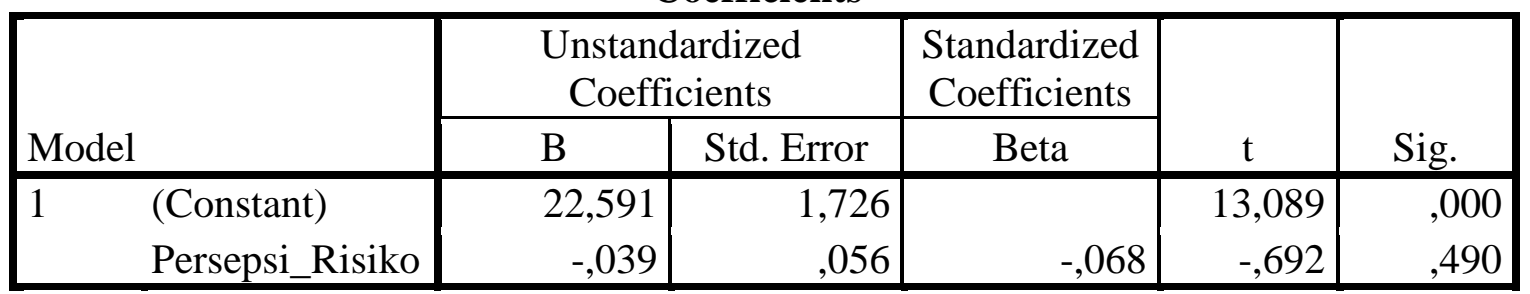

a. Dependent Variable: Keputusan_Pembelian

Sumber: Data diolah dengan SPSS 22

Dari perhitungan di atas, diperoleh nilai persamaan regresi linier sederhana sebagai berikut :

$$
\hat{\mathrm{Y}}=22,591(\mathrm{a})+-0.039\left(\mathrm{X}_{2}\right)
$$

Berdasarkan persamaan garis regresi tersebut dapat diinterpretasikan sebagai berikut :

(1) Nilai konstanta (a)

Nilai a sebesar 22,591, hal ini menunjukkan apabila tidak ada persepsi risiko $(X=0)$, maka perkiraan keputusan pembelian diperoleh sebesar 22,591.

(2) Pengaruh persepsi risiko $\left(X_{2}\right)$ terhadap keputusan pembelian $(\mathrm{Y})$ Nilai b sebesar -0.039 , menunjukkan bahwa pengaruh persepsi risiko bersifat negatif, dan hal ini menjelaskan bahwa setiap perubahan persepsi risiko sebesar 1 satuan tidak akan meningkatkan keputusan pembelian.

\section{4) Analisis Regresi Linier Berganda}

Perhitungan regresi linier berganda digunakan untuk memprediksi besarnya hubungan antara variabel terikat (dependen) yaitu Keputusan Pembelian (Y), dengan variabel bebas (independen) yaitu Kepercayaan $\left(\mathrm{X}_{1}\right)$, dan Persepsi Risiko $\left(\mathrm{X}_{2}\right)$.

Hasil regresi linier berganda dapat dilihat di bawah ini :

Tabel IV.38 Hasil Uji Regresi Berganda

Coefficients $^{\mathbf{a}}$

\begin{tabular}{|c|c|c|c|c|c|c|}
\hline \multirow{2}{*}{\multicolumn{2}{|c|}{ Model }} & \multicolumn{2}{|c|}{$\begin{array}{c}\text { Unstandardized } \\
\text { Coefficients }\end{array}$} & \multirow{2}{*}{$\begin{array}{c}\text { Standardized } \\
\text { Coefficients } \\
\text { Beta }\end{array}$} & \multirow[b]{2}{*}{$\mathrm{t}$} & \multirow[b]{2}{*}{ Sig. } \\
\hline & & $\mathrm{B}$ & Std. Error & & & \\
\hline \multirow[t]{3}{*}{1} & (Constant) & 13,575 & 2,762 & & 4,915 &, 000 \\
\hline & kepercayaan &, 430 & 107 & ,369 & 4,020 &, 000 \\
\hline & persepsi_risiko &,- 042 & 053 &,- 073 &,- 796 & ,428 \\
\hline
\end{tabular}

a. Dependent Variable: keputusan_pembelian

Sumber: Data primer diolah menggunakan SPSS 22 
Heksawan Rahmadi \& Deni Malik, Pengaruh Kepercayaan Dan Persepsi Risiko ...

Berdasarkan output coefficient ini, akan dibuktikan hipotesis secara parsial, beta pengaruh yang dihasilkan, serta pembentukan persamaan regresi. Persamaan regresi linier dalam penelitian ini dapat dibentuk dari hasil Coeficient pada kolom Standardized Coefficients adalah sebagai berikut :

$$
\begin{gathered}
\mathrm{Y}=\alpha+\beta\left(\mathrm{X}_{1}\right)+\beta\left(\mathrm{X}_{2}\right) \\
\mathrm{Y}=13,575+0,369\left(\mathrm{X}_{1}\right)+-0,073\left(\mathrm{X}_{2}\right)
\end{gathered}
$$

Yang mempunyai pengertian sebagai berikut :

(1) $\alpha=13,575$ yang berarti apabila variabel $\quad \mathrm{X}_{1} \quad$ (kepercayaan) mempunyai nilai sebesar 0 (tidak ada) maka variabel Y (keputusan pembelian) mempunyai nilai sebesar 13,575.

(2) $\beta=0,369$ yang berarti apabila setiap kenaikan variabel $\mathrm{X}_{1}$ (kepercayaan) sebesar satu satuan maka akan menaikan variabel $\mathrm{Y}$ (keputusan pembelian) sebesar
0,369 satuan dengan konstanta 0.369 dan begitu juga sebaliknya.

(3) $\alpha=13,575$ yang berarti apabila setiap variabel $\mathrm{X}_{2}$ (persepsi risiko) mempunyai nilai sebesar 0 (tidak ada) maka variabel Y (keputusan pembelian) mempunyai nilai sebesar 13,575.

(4) $\beta=-0,073$ yang berarti apabila setiap kenaikan variabel $\mathrm{X}_{2}$ (persepsi risiko) sebesar satu satuan maka tidak akan menaikan variabel Y (keputusan pembelian) dan begitu juga sebaliknya.

\section{5) Uji t (Secara Parsial)}

Pengujian hipotesis ini untuk mengetahui apakah variabel independen berpengaruh sendiri-sendiri terhadap variabel terikat dan variabel independen (bebas) manakah yang paling dominan pengaruhnya terhadap keputusan pembelian.

Tabel IV.39 Hipotesis Uji t

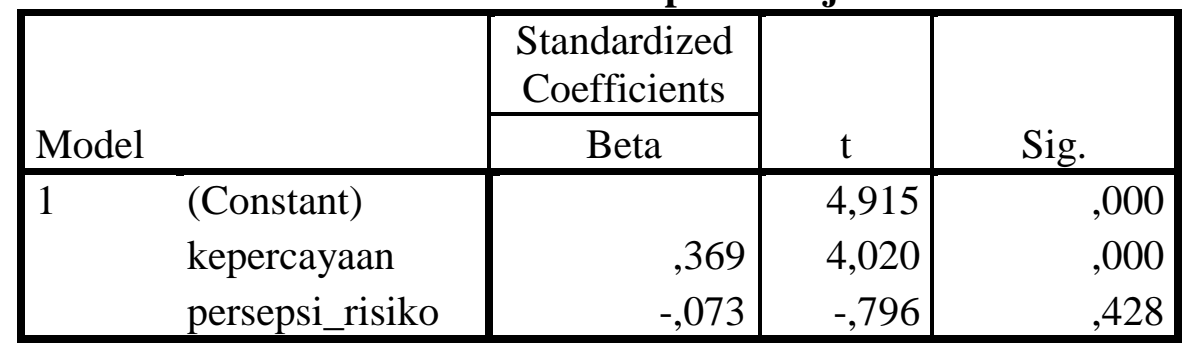

Sumber: Data primer diolah menggunakan SPSS 22

Dari hasil Uji $\mathrm{t}$ dari tabel IV.39 menunjukkan bahwa hanya terdapat 1 variabel independen (X) mempunyai pengaruh yang signifikan terhadap variabel dependen (Y). Secara rinci dapat dijelaskan sebagai berikut:

(1) Kepercayaan $\left(X_{1}\right)$

Kepercayaan berpengaruh secara signifikan terhadap Keputusan Pembelian. Tabel Coefficient pada kolom sig. Menunjukan bahwa pengaruh Kepercayaan $\left(\mathrm{X}_{1}\right)$ terhadap Keputusan Pembelian (Y) adalah signifikan, karena Sig. 0,000 $<0,05$. Hasil $t_{\text {hitung }}$ menunjukan bahwa $t_{\text {hitung }}$ $4,020>\mathrm{t}_{\text {tabel }} 1,983$.
Hal ini berarti bahwa secara parsial (secara individu) variabel kepercayaan $\left(\mathrm{X}_{1}\right)$ terhadap keputusan pembelian (Y) berpengaruh signifikan. Hasil $t_{\text {tabel }}$ sebesar 1,983 dapat dilihat dari tabel distribusi t student uji dua arah, pada kolom 0,05 atau 5\% dan baris 103 (jumlah sampel dikurangi jumlah variabel bebas). Nilai $t_{\text {hitung }}$ untuk variabel kepercayaan $\left(\mathrm{X}_{1}\right)$ pada output Coefficient adalah sebesar 4,020.

Berdasarkan tabel di atas diperoleh $t_{\text {hitung }}$ sebesar 4,020 dan $\left.\mathrm{t}_{\text {tabel }(\mathrm{df}}=103\right)$ sebesar 1,983 untuk $\alpha$ sebesar $0,025_{(0,05 / 2)}$. Karena $t_{\text {hitung }}$ lebih besar dari $t_{\text {tabel }}(4,4,020>1,983)$, maka dapat disimpulkan bahwa 
Jurnal Ilmiah Untuk Mewujudkan Masyarakat Madani ISSN 2355-309X

variabel kepercayaan $\left(\mathrm{X}_{1}\right)$ berpengaruh signifikan terhadap variabel keputusan pembelian (Y).

Berdasarkan pembuktian ini maka dapat disimpulkan Hipotesis $\mathrm{H}_{0}$ ditolak dan $\mathrm{H}_{\mathrm{a}}$ diterima.

(2) Persepsi Risiko $\left(X_{2}\right)$

Persepsi risiko tidak berpengaruh secara signifikan terhadap keputusan pembelian. Tabel Coefficient pada kolom sig. menunjukan bahwa pengaruh persepsi risiko $\left(\mathrm{X}_{2}\right)$ terhadap keputusan pembelian (Y) adalah tidak signifikan, karena Sig. 0,428 > 0,05. Hasil $t_{\text {hitung }}$ menunjukan bahwa $t_{\text {hitung }}$ $0,796<\mathrm{t}_{\text {tabel }} 1,983$.

Hal ini berarti bahwa secara parsial (secara individu) variabel persepsi risiko $\left(\mathrm{X}_{2}\right)$ terhadap keputusan pembelian (Y) tidak berpengaruh signifikan.

Hasil $t_{\text {tabel }}$ sebesar 1,983 dapat dilihat dari tabel distribusi $\mathrm{t}$ student $\mathrm{uji}$ dua arah, pada kolom 0,05 atau 5\% dan pada baris 103 (jumlah sampel dikurangi jumlah variabel bebas). Nilai $t_{\text {hitung }}$ untuk variabel persepsi risiko $\left(\mathrm{X}_{2}\right)$ pada output Coefficient adalah sebesar $-0,796$.

Berdasarkan tabel di atas diperoleh $t_{\text {hitung }}$ sebesar -0, 796 dan $\left.t_{\text {tabel }(d f}=103\right)$ sebesar 1,983 untuk $\alpha$ sebesar $0,025_{(0,05 / 2)}$. Karena $t_{\text {hitung }}$ lebih kecil dari $t_{\text {table }}(-0,796<1,983)$, maka dapat disimpulkan bahwa variabel persepsi risiko $\left(\mathrm{X}_{2}\right)$ tidak berpengaruh signifikan terhadap variabel keputusan pembelian (Y).

Berdasarkan pembuktian ini maka dapat disimpulkan Hipotesis $\mathrm{H}_{\mathrm{o}}$ diterima dan $\mathrm{H}_{\mathrm{a}}$ ditolak.

\section{6) Uji F (Simultan)}

Pengujian hipotesis ini yaitu untuk mengetahui pengaruh antara seluruh variabel independen (bebas) dengan variabel dependen (terikat). Dalam hipotesis penelitian ini, diduga bahwa variabel kepercayaan $\left(\mathrm{X}_{1}\right)$ dan variabel persepsi risiko $\left(\mathrm{X}_{2}\right)$ secara serempak (simultan) mempengaruhi keputusan pembelian (Y).

Hasil pengujian hipotesis uji $\mathrm{F}$ dapat dilihat pada tabel berikut :

\section{Tabel IV.40 Hasil Uji F (Anova)}

\begin{tabular}{|c|c|c|c|c|c|c|}
\hline \multicolumn{7}{|c|}{ ANOVA $^{a}$} \\
\hline \multicolumn{2}{|c|}{ Model } & $\begin{array}{c}\text { Sum of } \\
\text { Squares }\end{array}$ & df & Mean Square & $\mathrm{F}$ & Sig. \\
\hline 1 & Regression & 169,125 & 2 & 84,563 & 8,354 &, $000^{b}$ \\
\hline & Residual & 1032,437 & 102 & 10,122 & & \\
\hline & Total & 1201,562 & 104 & & & \\
\hline
\end{tabular}

a. Dependent Variable: keputusan_pembelian

b. Predictors: (Constant), persepsi_risiko, kepercayaan

Sumber: Data Primer Diolah menggunakan SPSS 22

Berdasarkan hasil perhitungan yang dapat dilihat pada tabel IV.40, pada kolom Sig. 0,000> 0,05, yang berarti bahwa variabel kepercayaan dan persepsi risiko secara bersama-sama (simultan) berpengaruh signifikan terhadap keputusan pembelian.

Cara kedua adalah dengan membandingkan antara $F_{\text {hitung }}$ sebesar $8,354>\mathrm{F}_{\text {tabel }} 3,08$ yang berarti bahwa variabel kepercayaan dan persepsi risiko, secara bersama sama (simultan) berpengaruh signifikan terhadap keputusan pembelian. Hasil $F_{\text {tabel }}$ dapat dilihat pada tabel distribusi $\mathrm{F}$, pada kolom 2 (Total seluruh variabel dikurangi jumlah variabel terikat) pada baris ke 103 (Total sampel dikurangi jumlah variabel terikat).

Kesimpulannya adalah bahwa kepercayaan dan persepsi risiko secara bersama-sama berpemgaruh signifikan terhadap keputusan pembelian. Berdasarkan pembuktian ini maka dapat 
Heksawan Rahmadi \& Deni Malik, Pengaruh Kepercayaan Dan Persepsi Risiko ...

disimpulkan Hipotesis $\mathrm{H}_{0}$ ditolak dan $\mathrm{H}_{\mathrm{a}}$ diterima.

\section{7) Koefisien Determinasi (Adjusted $\mathbf{R}^{2}$ )}

Koefisien determinasi berganda $\left(\mathrm{R}^{2}\right)$ adalah kuadrat koefisien korelasi. Koefisien determinasi menunjukan proporsi variasi variabel dependen yang bisa dijelaskan oleh variabel independen.

Untuk mengetahui proporsi variasi keputusan pembelian yang bisa dijelaskan oleh variabel kepercayaan $\left(\mathrm{X}_{1}\right)$ dan persepsi risiko $\left(\mathrm{X}_{2}\right)$ disajikan model Output SPSS versi 22 sebagai berikut :

\section{Tabel IV.41 Hasil Koefisien Determinasi (Model Summary)}

\begin{tabular}{|l|r|r|c|c|}
\hline Model & R & R Square & $\begin{array}{c}\text { Adjusted R } \\
\text { Square }\end{array}$ & $\begin{array}{c}\text { Std. Error of the } \\
\text { Estimate }\end{array}$ \\
\hline 1 &, $375^{\text {a }}$ &, 141 &, 124 & 3,181 \\
\hline
\end{tabular}
a. Predictors: (Constant), Persepsi_Risiko, Kepercayaan
b. Dependent Variable: Keputusan_Pembelian

Sumber: Data Primer diolah menggunakan SPSS 22

Model Summary menunjukkan Koefisien Determinasi Adjust $R$ Square sebesar 0,141 atau sebesar $14,1 \%$. Artinya variasi kepercayaan dan persepsi risko memberikan kontribusi terhadap variasi keputusan pembelian adalah sebesar $14,1 \%$, sedangkan sisa sebesar $85,9 \%$ dipengaruhi oleh faktor-faktor lain.

\section{KESIMPULAN}

Berdasarkan hasil analisis dengan bantuan SPSS, maka dapat disimpulkan bahwa :

1. Besarnya pengaruh kepercayaan terhadap keputusan pembelian e-commerce pada Tokopedia.com di Jakarta Pusat sebesar 13.5\%. Oleh karena itu dapat dikatakan bahwa terdapat pengaruh yang positif dan signifikan antara kepercayaan $\left(\mathrm{X}_{1}\right)$ terhadap keputusan pembelian (Y). Hal tersebut ditunjukkan dari hasil uji $t_{\text {hitung }}$ sebesar 4,020 dengan signifikansi 0,000.

2. Besarnya pengaruh persepsi risiko terhadap keputusan pembelian ecommerce pada Tokopedia.com di Jakarta Pusat sebesar 5\%. Namun, Tidak terdapat pengaruh yang signifikan antara persepsi risiko $\left(\mathrm{X}_{2}\right)$ terhadap keputusan pembelian (Y). Hal tersebut ditunjukkan dari hasil uji $t_{\text {hitung }}$ sebesar $-0,796$ dengan signifikansi 0,428 .

3. Besarnya pengaruh kepercayaan dan persepsi risiko terhadap keputusan pembelian e-commerce pada Tokopedia.com di Jakarta Pusat sebesar $14.1 \%$. Oleh karena itu dapat dikatakan bahwa terdapat pengaruh yang signifikan antara kepercayaan $\left(\mathrm{X}_{1}\right)$ dan persepsi risiko $\left(\mathrm{X}_{2}\right)$ terhadap keputusan pembelian (Y). Hal tersebut ditunjukkan dari hasil uji F hitung sebesar 8,354 dengan signifikansi sebesar 0,000 .

\section{SARAN}

Berdasarkan hasil penelitian, pembahasan, dan kesimpulan yang dipeoleh, maka saran yang dapat diberikan sebagai berikut :

1. Bagi Tokopedia.com

a. Dalam penelitian ini, perusahaan disarankan agar terus meningkatkan kepercayaan konsumen Tokopedia.com dengan memberikan jaminan yang pasti pada setiap pembelian produk, sebab pada penelitian ini kepercayaan telah mempengaruhi keputusan pembelian secara online pada situs Tokopedia.com 
Jurnal Ilmiah Untuk Mewujudkan Masyarakat Madani

ISSN 2355-309X

b. Dalam penelitian ini indikator mengenai risiko kehilangan uang, keamanan dan penjaminan infromasi menjadi hal yang sangat penting bagi para konsumen. Untuk itu perusahaan diharapkan dapat terus mengupayakan pembenahan sistem yang ada sehingga pengguna (toppers) tidak memiliki persepsi yang berlebihan terhadap pembelian secara online di Tokopedia.com.

c. Dalam penelitian ini, perusahaan disarankan agar memperbaiki kualitas pelayanan baik sebelum atau setelah pengguna (toppers) telah memutuskan membeli produk di Tokopedia.com, sehingga apabila terdapat komplain pelanggan maka perusahaan dapat lebih cepat menanggapinya. Jika hal tersebut berjalan dengan baik, maka akan berdampak pula pada perekomendasian pembelian produk.

2. Bagi Peneliti Selanjutnya

Peneliti selanjutnya dapat mengembangkan penelitian ini dengan melakukan penelitian pada faktor-faktor lain yang dapat memPengaruhi keputusan pembelian. Besarnya faktor kepercayaan dan persepsi risiko terhadap keputusan pembelian e-commerce adalah $14,1 \%$ dan sisanya merupakan faktorfaktor lain yang mempengaruhi keputusan pembelian selain faktor yang diteliti dalam penelitian ini. Untuk itu peneliti selanjutnya diharapkan dapat menganalisis faktor-faktor lain yang memberikan kontribusi terhadap keputusan pembelian secara online di Tokopedia.com.

\section{DAFTAR PUSTAKA}

Aberg, J. dan Shahmehri, N., 2000. The Role of Human Web Assistants in ECommerce: an Analysis and a Usability Study, Internet Research: Electronic Networking Applications and Policy, 10(2): 114-125

Adi Nugroho, 2006. E-Commerce; Memahami Perdagangan Modern di Dunia Maya, Informatika Bandung. Bandung
Adi Sulistyo Nugroho, 2016 E-commerce Teori dan Implementasi Ekuilibria, Yogyakarta.

Arikunto, Suharsimi. 2006. Prosedur penelitian suatu pendekatan praktek. Jakarta: PT Rineka Cipta.

Dan J.Kim et al., yang berjudul " $A$ trustbased consumer decision-making model in electronic commerce : The role of trust, perceived risk, and their antecedents".

Engel, J.F., R.D, Blackwell., and P.W, Miniard, 1995. Perilaku Konsumen. Jakarta: Binarupa Aksara.

Fajar Arie Haryosasongko (2015 dengan judul Pengaruh Persepsi Risiko, Persepsi Kemudahan, Dan Persepsi Manfaat Terhadap Minat Pembelian Online Pada Website Lazada.co.id di Kota Malang.

Ferraro, A., 2008. Electronic Commerce: The Issues and Challenges to Creating Trust and a Positive Image in Consumer Sales on the World Wide Web, First Monday: Peer-Reviewed Journal on The Internet, 3 (6),http://www.firstmonday.org/issue s/issue3_6/ferraro/index.html

Haryadi, Hendi. 2009. Administrasi Perkantoran Untuk Manajer dan Staf. Jakarta : Visimedia.

Javalgi, R. dan Ramsey, R., 2001. Strategic Issues of E-Commerce as an Alternative Global Distribution System, International Marketing Review, 18 (4): 376-391

Kim, D. J., Ferrin, D. L., dan Rao, H.R., 2003a. Antecedents of Consumer Trust in B-to-C Electronic Commerce, Proceedings of Ninth Americas Conference on Information Systems, pp. 157-167

Kotler, Philip dan Kevin Lane Keller. (2009). Manajemen Pemasaran. Edisi 13 Jilid 1. Jakarta: Erlangga.

Koufaris, M.,Hampton-Sosa, W,.(2004), The development of initial trust in an online company by new customers, Information and Management, January, (41:3), pp.377-397

Liao, Z., dan Cheung, M.T. (2001). An Analytical Framework for Evaluating 
Heksawan Rahmadi \& Deni Malik, Pengaruh Kepercayaan Dan Persepsi Risiko ...

E-Commerce Business Models and Strategies. Internet Research: Electronic Networking Applications and Policy. Vol.11, No.4.

Mayer, R.C., Davis, J. H., dan Schoorman, F.D., 1995. An Integratif Model of Organizational Trust, Academy of Management Review, 30 (3): 709-734

Muhammad Luthfi (2015) dengan judul Analisa Search Engine Optimitation (SEO) pada Social Media Google Plus dan Youtube dalam Meningkatkan Keterlibatan dan Akusisi Pengguna Social Media Perusahaan PT. Tokopedia

Pavlou, P.A. (2010), "Consumer acceptance of electronic commerce: Integrating trust and risk with the technology acceptance model." International Journal of Electronic Commerce, Vol.7 (3)

Pavlou, P.A., dan Gefen, D., 2002. Building Effective Online Marketplaces with Institution-based Trust, Proceedings of Twenty-Third International Conference on Information Systems, pp. 667-675

Perpustakaan Universitas Indonesia. Ecommerce. www.digilibui.ac.id Information. Diakses 04 Oktober 2016.

Prasetyo Agus Nurrahmanto (2015) dengan judul Pengaruh Kemudahan Penggunaan, Kenikmatan Berbelanja, Pengalaman Berbelanja Dan Kepercayaan Konsumen Terhadap Minat Beli Konsumen Di Situs Jual Beli Online Bukalapak.com

Rofiq, Ainur. (2007). Pengaruh Dimensi Kepercayaan (Trust) Terhadap Partisipasi Pelanggan E-Commerce (Studi pada Pelanggan E-Commerce di Indonesia). Malang: Universitas Brawijaya.
Safina Novitasari (2014) dengan judul Pengaruh Kepercayaan, Persepsi Risiko, Persepsi Manfaat, dan Persepsi Kontrol Perilaku Terhadap Niat Penggunaan Sistem E-commerce Sarwono, Jonathan, \& Martadiredja Tutty. (2008), Teori E-Commerce Kunci Sukses Perdagangan di Internet Yogyakarta: Gava Media.

Sounders, Mark, Philp Lewis, Research Methods \& Adrian for The Business Students". Ed5. London: Pearson Education.

Sproule, S. dan Archer, N., 2000, A Buyer Behaviour Framework for The Development and Design of Software Agents in E-Commerce, Internet Research: Electronic Networking Applications and Policy, 10 (5): 396405.

Sugiyono. 2009. Metode Penelitian Kuantitatif dan Kualitatif. Bandung: CV.Alfabeta.

Teropong Senayan. 2015. Kacau, Karena Merasa Ditipu Sejumlah Massa Demo Tokopedia. http://teropongsenayan.com

Information. Diakses 08 Oktober 2016

Tjiptono, Fandy, Gregorius Candra, \& Dadi Adriana. (2008), Pemasaran Strategik. Yogyakarta: Andi Offset.

Ustadiyanto, R., 2001. Framework eCommerce. Edisi Pertama. Penerbit Andi. Yogyakarta.

Yusuf Fitra Mulyana (2016 dengan judul Pengaruh KepercayaaN, Persepsi Risiko, dan Kemanan Terhadap Minat Beli Konsumen Pada Toko Online (Studi Pada Toko Online OLX.co.id)

Zikmund, William G., Barry J. Babin, Jon C. Carr, \& Mitch Griffin. (2009). Business Research Methods". 8th WesternEd. CollegeSouthPub. 